\title{
Pengaruh Kecukupan Modal dan Penyaluran Kredit Terhadap Profitabilitas Perbankan
}

\author{
1) Rifqi Zul Fahmi, 2) Herman Sjahruddin, 3) Niken Probondani Astuti, \\ 4) A. Muh. Syakhrun
1) Mahasiswa Program Studi Manajemen pada Sekolah Tinggi Ilmu Ekonomi Bongaya Makassar \\ 2, 3,4) Dosen Program Studi Manajemen pada Sekolah Tinggi Ilmu Ekonomi \\ Bongaya Makassar
}

Abstrak

Riset ini mencoba mengeksplorasi pengaruh Kecukupan Modal dan Penyaluran Kredit terhadap Profitabilitas pada PT. Bank Negara Indonesia Tbk., PT. Bank Rakyat Indonesia Tbk, dan PT. Bank Tabungan Negara Tbk, serta PT. Bank Mandiri Tbk Tahun 2011-2014. Pendekatan penelitian ini menggunakan pendekatan kuantitatif. Pengambilan data pada penelitian ini dilaksanakan pada pusat informasi pasar modal Makassar perwakilan Bursa Efek Indonesia. Data dihitung secara proporsional dalam bentuk persentase untuk setiap triwulannya, sehingga jumlah data yang akan dianalisis sebanyak 64 unit data yang sekaligus digunakan sebagai sampel. Hasil analisis regresi ganda memberikan bukti bahwa Kecukupan Modal (Capital Adequacy Ratio) beperngaruh positif tidak signifikan dan Penyaluran Kredit berpengaruh positif signifikan terhadap Profitabilitas

Kata Kunci : CAR, Kredit, ROA, Perbankan BUMN

\section{A. Latar Belakang}

Lembaga perbankan merupakan salah satu tulang punggung perekonomian suatu negara, karena memiliki fungsi intermediasi atau sebagai perantara antara pemilik modal (fund supplier) dengan penguna dana (fund user) sehingga melancarkan kegiatan perekonomian suatu negara. Bank merupakan lembaga keuangan terpenting dan sangat mempengaruhi perekonomian baik secara mikro maupun secara makro. Seperti yang diketahui, perbankan mempunyai pangsa pasar besar sekitar $80 \%$ dari keseluruhan sistem keuangan yang ada (Laporan Bank Indonesia (BI), 2010:4). Bank persero Badan Umum Miliki Negara (BUMN) memiliki peranan penting dalam industri perbankan di Indonesia, berdasarkan data yang dihimpun dari Bank Indonesia, bank BUMN memiliki asset, modal dan profitabilitas yang terus meningkat.

Profitabilitas merupakan cerminan dari kinerja keuangan perbankan, dalam Jensen dan Meckling (1967) dalam Isnanta (2008), menyatakan bahwa teori keagenan mendeskripsikan pemegang saham sebagai prinsipal dan manajemen sebagai agen.Manajemen merupakan pihak yang dikontrak oleh pemegang saham untuk bekerja demi kepentingan pemegang saham.Untuk itu manajemen diberikan sebagian kekuasaan untuk membuat keputusan bagi kepentingan terbaik pemegang saham. Oleh karena itu, manajemen wajib mempertanggungjawabkan semua upayanya kepada pemegang saham.Karena unit analisis dalam teori keagenan Author : Rifqi Zul Fahmi dkk. (2016) 27 - 43 Jurnal Ilmiah BONGAYA (Manajemen \& Akuntansi) No. XIX April 2016 ISSN : $1907-5480$ 
adalah kontrak yang melandasi hubungan antara prinsipal dan agen, maka fokus dari teori ini adalah pada penentuan kontrak yang paling efisien yang mendasari hubungan antara prinsipal dan agen.Berdasarkan teori tersebut, masalah keagenan dapat terjadi dalam 2 bentuk hubungan, yaitu; (1) antara pemegang saham dan manajer, dan (2) antara pemegang saham dan kreditor.

Jika suatu perusahaan berbentuk perusahaan perorangan yang dikelola sendiri oleh pemiliknya, maka dapat diasumsikan bahwa manajer- pemilik akan mengambil setiap tindakan yang mungkin, untuk memperbaiki kesejahteraannya, terutama diukur dalam bentuk peningkatan kekayaan perorangan dan juga dalam bentuk kesenangan dan fasilitas eksekutif faktor utama yang mempengaruhi yaitu kemampuan (Owner-0) x (Manager-M) x yaitu Rich = R (O x M ), yang artinya Rich (profitabilitas) merupakan fungsi dari kemampuan (kemampuan dicirikan pada melalui kecukupan permodalan yang dimiliki perbankan), usaha merupakan refleksi dari penyaluran kredit perbankan.

Berdasarkan teori tersebut dapat dinyatakan bahwa penciptaan profitabilitas sebagai perwujudan dari kinerja dipengaruhi oleh kemampuan perbankan dalam memenuhi kecukupan modalnya, sedangkan penyaluran kredit merupakan refleksi dari usaha perbankan. Bahwa tinggi dan rendahnya profitabilitas perbankan sangat dipengaruhi oleh kecukupan modal dan jumlah kredit yang disalurkan oleh bank. Lestari dan Sugiharto (2007: 196) dapat ditunjukkan dengan return on asset (ROA)yang merupakan rasio antara laba sebelum pajak terhadap total asset,semakin tinggi rasio ini maka semakin baik produktivitas asset dalam memperoleh keuntungan bersih. Kondisi tersebut meningkatkan daya tarik perusahaan kepada investor. Peningkatan daya tarik perusahaan menjadikan perusahaan tersebut semakin diminati oleh investor, karena tingkat pengembalian atau deviden akan semakin besar. Adapun data ROA (return on asset) pada Bank BUMN (badan usaha milik negara) periode 2011-2014 dapat dilihat pada tabel dibawah ini:

Tabel 1. ROA Bank BUMN Periode 2011-2014

\begin{tabular}{|c|c|c|}
\hline Tahun & ROA (\%) & Perkembangan (\%) \\
\hline 2011 & 3,60 & 23.97 \\
\hline 2012 & 3,80 & 25.30 \\
\hline 2013 & 3,87 & 25.77 \\
\hline 2014 & 3,75 & 24.97 \\
\hline Total & 15.02 & 100 \\
\hline
\end{tabular}

Sumber : Statistik Perbankan Indonesia (Otoritas Jasa Keuangan, 2015)

Berdasarkan Tabel Tabel. 1. ROA Bank BUMN Periode 2011-2014, menunjukkan Statistik Perbankan Indonesia tahun 2011-2014 bank BUMN mengalami peningkatan sebesar 3,60\% (2011), 3,80\% (2012), 3,87\% (2013), dan pada akhir desember 2014 mengalami penurunan sebesar 3,75\%. Hal menunjukkan bahwa kinerja keuangan yang ditunjukkan melalui profitabilitas pada bank persero belum optimal.

Author : Rifqi Zul Fahmi dkk. (2016) 27 - 43

Jurnal Ilmiah BONGAYA (Manajemen \& Akuntansi) No. XIX April 2016

ISSN : $1907-5480$ 
Pemberian kredit merupakan aktivitas bank yang paling utama dalam menghasilkan keuntungan, tetapi risiko yang terbesar dalam bank juga bersumber dari pemberian kredit.Risiko kredit ini berkaitan dengan faktor internal maupun faktor eksternal.Faktor eksternal seperti debitur yang tidak mampu membayar pinjaman dan keadaan ekonomi di negara.Sedangkan faktor internal dapat diukur dengan jumlah kecukupan modal sebagai faktor internal bank yang juga berpengaruh atas tingkat kesehatan bank yang mewakili kecukupan modal bank. Modal yang cukup akan membantu kegiatan operasional.

CAR (Capital Adequacy Ratio) adalah rasio kecukupan modal yang berfungsi menampung risiko kerugian yang kemungkinan dihadapi oleh bank.Semakin tinggi CAR maka semakin baik kemampuan bank tersebut untuk menanggung risiko dari setiap kredit/aktiva produktif yang berisiko. Kemampuan perbankan dalam menyalurkan kredit bergantung pada capital adequacy ratio yang dimilikinya, semakin tinggi CAR yang dimiliki perbankan maka semakin tinggi tingkat kemampuan bank dalam menyalurkan kredit, begitupun sebaliknya.Penyaluran kredit memungkinkan masyarakat untuk melakukan investasi, distribusi, danjuga konsumsi barang dan jasa, mengingat semua kegiatan investasi, distribusi, dan konsumsi selalu berkaitan dengan penggunaan uang. Kelancaran kegiatan investasi, distribusi, dan konsumsi ini tidak lain adalah kegiatan pembangunan perekonomian masyarakat. Melalui fungsi ini bank berperan sebagai Agent of Development (Triandaru dan Santoso, 2006:9). Keterikatan kondisi kecukupan modal, penyaluran kredit dan Return On Asset (ROA) Bank Persero selama Tahun 2011 sampai dengan 2014 ditunjukkan pada Tabel 1.2 dibawah ini:

Tabel 2. Perkembangan Kecukupan Modal, Penyaluran Kredit, dan Profitabilitas/ROA Bank Persero Periode 2011-2014

\begin{tabular}{|c|c|c|c|}
\hline Tahun & $\begin{array}{c}\text { Kecukupan } \\
\text { Modal (\%) }\end{array}$ & $\begin{array}{c}\text { Penyaluran } \\
\text { Kredit (miliar) }\end{array}$ & $\begin{array}{c}\text { Profitabilitas/ROA } \\
(\%)\end{array}$ \\
\hline 2011 & 15,04 & 776.833 & 3,6 \\
\hline 2012 & 16,17 & 961.994 & 3,11 \\
\hline 2013 & 15,91 & 1.187 .431 & 3,08 \\
\hline 2014 & 17,08 & 1.329 .941 & 2,85 \\
\hline
\end{tabular}

Sumber : Statistik Perbankan Indonesia (www.ojk.go.id, 2017)

Tabel 2 menunjukkan bahwa kecukupan modal pada tahun 2011-2012 mengalami peningkatan $(15,04 \%$ menjadi $16,17 \%)$, searah dengan Profitabilitas yang mengalami peningkatan (3,6\% menjadi 3,11\%). Pada tahun 2012-2013 Kecukupan Modal mengalami penurunan $(16,17 \%$ menjadi $15,91 \%)$, searah dengan Profitabilitas yang menurun (3,11\% menjadi 3,08\%). Dan pada tahun 2013-2014, Kecukupan Modal mengalami peningkatan (15,91\% menjadi 17,08\%) tidak searah dengan Kredit yang menunjukkan penurunan (3,08\% menjadi $2,85 \%)$.

Penyaluran Kredit pada tahun 2011-2012 menunjukkan peningkatan (776.833 menjadi 961.994), searah dengan Profitabilitas yang mengalami peningkatan $(3,6 \%$ menjadi 3,11\%). Sedangkan pada tahun 2012-2013, Penyaluran Kredit mengalami peningkatan (961.994 menjadi 1.187.431), tidak searah dengan Kredit yang

Author : Rifqi Zul Fahmi dkk. (2016) 27 - 43

Jurnal Ilmiah BONGAYA (Manajemen \& Akuntansi) No. XIX April 2016

ISSN : $1907-5480$ 
menunjukkan penurunan (3,11\% menjadi 3,08\%). Dan pada tahun 2013-2014, Penyaluran Kredit mengalami peningkatan (1.187.431 menjadi 1.329.941), tidak searah dengan Kredit yang mengalami peningkatan $(3,08 \%$ menjadi 2,85\%).Berdasarkan tabel 1.2 tampak pada variabel Kecukupan Modal dan Penyaluran Kredit tidak memiliki konsistensi hubungan searah antara Profitabilitas pada tahun 2011-2014.Hal ini mengindikasikan bahwa pertumbuhan Kecukupan Modal dan Penyaluran Kredit merupakan faktor - faktor yang mempengaruhi besar kecilnya penyaluran kredit pada bank.

Faktor-faktor yang mempengaruhi tingkat profitabilitas perbankan, antara lain pengaruh kecukupan modal dan penyaluran kredit. Hal ini ditunjukkan pada peneliti terdahulu oleh Firmansyah (2013) hasil penelitian menunjukan bahwa kecukupan modal berpengaruh positif dan signifikan terhadap profitabilitas bank persero. Sementara penyaluran kredit berpengaruh negatif dan signifikan terhadap profitabilitas tidak berpengaruh.Diantara semua variabel bebas yang diteliti, penyaluran kredit menjadi variabel yang paling dominan mempengaruhi profitabilitas.

Peneliti lainnya yang menganalisis profitabilitas perbankan dilakukan oleh Wisnu Mawardi (2004) hasil penelitiannya membuktikan bahwa secara uji simultan variabel penyaluran kredit berpengaruh terhadap profitabilitas dan secara uji parsial variable ROA berpengaruh positif dan signifikan terhadap profitabilitas. Berdasarkan fakta-fakta yang dikemukakan, maka penelitian ini dilakukan pada Perbankan BUMN disebabkan karena perbankan BUMN memiliki rasio kecukupan modal yang lebih tinggi dibandingkan Perbankan Swasta (BUMN x 16,05\% sedangkan perbankan swasta 10.02\% (Tahun 2011-2014)). Alasan lainnya, bahwa terdapat ketidaksamaan temuan dari para peneliti terdahulu dalam menganalisis profitabilitas perbankan (Firmansyah, 2013;Mawardi,2004)

\section{B. Tinjauan Teroritis}

\section{Pengertian Bank dan Jenis - Jenis Bank}

Bank adalah sebuah lembaga perantara keuangan yang memiliki wewenang dan fungsi untuk menghimpun dana masyarakat umum untuk disalurkan. Sedangkan menurut Undang-undang Negara Republik Indonesia Nomor 10 Tahun 1998 Tanggal 10 November 1998 tentang perbankan, yang dimaksud dengan bank adalah badan usaha yang menghimpun dana dari masyarakat dalam bentuk simpanan dan menyalurkannya kepada masyarakat dalam bentuk kredit dan atau bentuk-bentuk lainnya dalam rangka meningkatkan taraf hidup rakyat banyak. Dari definisi bank di atas dapat ditarik kesimpulan, yaitu bank merupakan suatu lembaga dimana kegiatannya menghimpun dana dari masyarakat dalam bentuk simpanan, seperti tabungan, deposito, maupun giro, dan menyalurkan dana simpanan tersebut kepada masyarakat yang membutuhkan, baik dalam bentuk kredit maupun bentukbentuk lainnya.

\section{Kecukupan Modal (CAR)}

Kecukupan Modal atau CAR (Capital Adequacy Ratio) adalah rasio kecukupan modal yang berfungsi menampung risiko kerugian yang kemungkinan dihadapi oleh bank.Semakin tinggi CAR maka semakin baik kemampuan bank tersebut untuk menanggung risiko dari setiap kredit/aktiva

Author : Rifqi Zul Fahmi dkk. (2016) 27 - 43

Jurnal Ilmiah BONGAYA (Manajemen \& Akuntansi) No. XIX April 2016

ISSN : $1907-5480$ 
produktif yang berisiko.Jika nilai CAR tinggi maka bank tersebut mampu membiayai kegiatan operasional dan memberikan kontribusi yang cukup besar bagi profitabilitas.

Capital Adequacy Ratio menurut Dendawijaya (2009:121) adalah Rasio yang memperlihatkan seberapa jauh seluruh aktiva bank yang mengandung risiko (kredit, penyertaan, surat berharga, tagihan pada bank lain) ikut dibiayai dari dana modal sendiri bank disamping memperoleh dana-dana dari sumbersumber di luar bank, seperti dana dari masyarakat, pinjaman, dan lain-lain.CAR merupakan indikator terhadap kemampuan bank untuk menutupi penurunan aktivanya sebagai akibat dari kerugian - kerugian bank yang di sebabkan oleh aktiva yang berisiko.

Perhitungan Capital Adequacy Ratio didasarkan pada prinsip bahwa setiap penanaman yang mengandung risiko harus disediakan jumlah modal sebesar persentase tertentu terhadap jumlah penanamannya. Sejalan dengan standar yang ditetapkan Bank of International Settlements (BIS), seluruh bank yang ada di Indonesia diwajibkan untuk menyediakan modal minimum sebesar $8 \%$ dari ATMR.Menurut Surat Edaran Bank Indonesia No. 6/23/DPNP tanggal 31 Mei 2004 rumus Capital Adequacy Ratio (CAR) sebagai berikut :

$$
=\frac{\text { MODAL SENDIRI }}{\text { ATMR }} \quad 100 \%
$$

Modal terdiri dari Modal Inti dan Modal Pelengkap. Modal Inti terdiri dari modal disetor dan cadangan tambahan modal yang terdiri dari faktor penambah (agio, modal sumbangan, cadangan umum modal, cadangan tujuan modal, laba tahun - tahun lalu setelah diperhitungkan pajak, laba tahun berjalan setelah diperhitungkan taksiran pajak (50\%), selisih lebih penjabaran laporan keuangan kantor cabang luar negeri, dan dana setoran modal) dan faktor pengurang (disagio, rugi tahun - tahun lalu, rugi tahun berjalan, selisih kurang penjabaran laporan keuangan kantor cabang di luar negeri, dan penurunan nilai penyertaan pada portofolio yang tersedia untuk dijual).

Modal Inti diperhitungkan dengan faktor pengurang berupa goodwill. Modal Pelengkap terdiri dari cadangan revaluasi aktiva tetap, cadangan umum PPAP (maksimal 1,25\% dari ATMR), modal pinjaman, pinjaman subordinasi (maksimal $50 \%$ dari Modal Inti), dan peningkatan nilai penyertaan pada portofolio yang tersedia untuk dijual setinggi - tingginya sebesar 45\%. Sedangkan ATMR (Aktiva Tertimbang Menurut Risiko) terdiri dari aktiva neraca yang diberikan bobot sesuai kadar risiko kredit yang melekat dan beberapa pos dalam off-balance sheet yang diberikan bobot sesuai dengan kadar risiko kredit yang melekat. ATMR diperoleh dengan cara mengalikan nilai nominal aktiva dengan bobot risiko. Semakin likuid aktiva risikonya nol dan semakin tidak likuid bobot risikonya 100, sehingga risiko berkisar antara 0 $100 \%$.

Semakin tinggi CAR maka semakin besar pula sumber daya finansial yang dapat digunakan untuk mengantisipasi potensi kerugian yang diakibatkan oleh penyaluran kredit. Secara singkat dapat dikatakan besarnya nilai CAR akan meningkatkan kepercayaan diri perbankan dalam menyalurkan kredit. Dengan CAR diatas 20\%, perbankan bisa memacu pertumbuhan kredit hingga 20 - 25

Author : Rifqi Zul Fahmi dkk. (2016) 27 - 43

Jurnal Ilmiah BONGAYA (Manajemen \& Akuntansi) No. XIX April 2016

ISSN : $1907-5480$ 
persen setahun.Kiat yang banyak ditempuh oleh bank untuk memperkuat CAR dalam rangka menggenjot ekspansi kredit pada tahun berikutnya adalah dengan penerbitan obligasi subordinasi (subdebt) dan right issue.

\section{Kredit dan Jenis - Jenis Kredit}

Menurut Kasmir (2014:85) kata kredit berasal dari kata credere atau creditum. Credere berasal dari bahasa Yunani yang berarti kepercayaan, sementara creditum berasal dari bahasa latin yang berarti kepercayaan akan kebenaran. Arti kata tersebut memiliki implikasi bahwa setiap kegiatan perkreditan harus dilandasi kepercayaan. Tanpa kepercayaan maka tidak akan terjadi pemberian kredit atau sebaliknya tidak ada calon nasabah menyepakati kredit, sebab pemberian kredit oleh bank mempunyai nilai ekonomi kepada nasabah perorangan atau badan usaha.

Pengertian kredit secara universal menurut undang-undang Perbankan Indonesia, yaitu:Penyediaan uang atau tagihan yang dapat dipersamakan dengan UU, berdasarkan persetujuan atau kesepakatan pinjam meminjam antara bank dengan pihak lain yang mewajibkan pihak peminjam untuk melunasi utangnya setelah jangka waktu tertentu dengan pemberian bunga. (Undang-undang Perbankan No. 10 Tahun 1998)

Pengertian kredit menurut Sigit Triandaru dan Totok Budisantoso (2006:113) adalah Pemberian fasilitas pinjaman (bukan berdasarkan prinsip syariah) kepada nasabah, baik berupa fasilitas pinjaman tunai (cash loan) maupun pinjaman nontunai (non-cash loan).

Berkaitkan dengan kegiatan usaha, kredit berarti suatu kegiatan memberikan nilai ekonomi kepada seseorang atau badan usaha berlandaskan kepercayaan saat itu, bahwa nilai ekonomi yang sama akan dikembalikan kepada kreditur setelah jangka waktu tertentu sesuai dengan kesepakatan yang sudah disetujui antara kreditur dan debitur. Dasar pemikiran persetujuan pemberian kredit oleh suatu lembaga keuangan atau bank kepada seseorang atau badan usaha berlandaskan kepercayaan. Seseorang atau suatu badan atau lembaga keuangan yang memberikan kredit percaya bahwa penerima kredit dimasa mendatang akan sanggup memenuhi segala sesuatu yang telah dijanjikan baik berupa barang, uang ataupun jasa.

Kredit yang diberikan bank umum dan bank pengkreditan rakyat untuk masyarakat terdiri dari berbagai jenis. Secara umum jenis - jenis kredit dapat dilihat dari berbagai segi anatara lain sebagai berikut (Kasmir, 2014:90).

1) Dari segi kegunaan

a) Kredit investasi, kredit investasi merupakan kredit jangka panjang yang biasanya digunakan untuk keperluan perluasan usaha atau membangun proyek/pabrik baru atau untuk keperluan rehabilitasi.

b) Kredit modal kerja, kredit modal kerja merupakan kredit yang digunakan untuk keperluan meningkatkan produksi dalam operasionalnya.

2) Dilihat dari segi tujuan kredit

a) Kredit produktif, kredit yang digunakan untuk peningkatan usaha atau produksi atau investasi.kredit ini diberikan untuk menghasilkan barang atau jasa.

Author : Rifqi Zul Fahmi dkk. (2016) 27 - 43

Jurnal Ilmiah BONGAYA (Manajemen \& Akuntansi) No. XIX April 2016

ISSN : 1907 - 5480 
b) Kredit konsumtif, kredit yang digunakan untuk dikonsumsi secara pribadi.dalam kredit ini tidak ada pertambahan barang dan jasa yang dihasilkan, karena memang untuk digunakan atau dipakai oleh seseorang atau badan usaha.

c) Kredit perdagangan, kredit yang diberikan kepada pedagang dan digunakan untuk membeli aktivitas perdagangannya seperti untuk membeli barang dagangan yang pembayarannya diharapkan dari hasil penjualan barang dagangan tersebut.

3) Dilihat dari segi jaminan

1) Kredit dengan jaminan, merupakan kredit yang diberikan dengan suatu jaminan.Jaminan tersebut dapat berbentuk barang berwujud atau tidak berwujud atau jaminan orang.

2) Kredit tanpa jaminan, merupakan kredit yang diberikan tanpa jaminan barang atau orang tertentu.

\section{Profitabilitas}

Profitabilitas adalah kemampuan perusahaan memperoleh laba dalam hubungannya dengan penjualan, total aktiva maupun modal sendiri. Menurut Kasmir (2012:196) , yang menyatakan bahwarasio profitabilitas merupakan rasio untuk menilai kemampuan perusahaan dalam mencari keuntungan. Menurut Irawati (2006:58), yang menyatakan bahwa rasio keuntungan atau profitability ratio adalah rasio yang digunakan untuk mengukur efisiensi penggunaan aktiva perusahaan atau merupakan kemampuan suatu perusahaan untuk menghasilkan laba selama periode tertentu (biasanya semesteran, triwulanan dan lain-lain) untuk melihat kemampuan perusahaan dalam beroperasi secara efisien.

Berdasarkan pendapat para ahli di atas, dapat ditarik kesimpulan bahwa rasio profitabilitas adalah rasio untuk mengukur tingkat efektifitas pengelolaan (manajemen) perusahaan yang ditunjukkan oleh jumlah keuntungan yang dihasilkan dari penjualan dan investasi. Intinya adalah penggunaan rasio ini menunjukkan efisiensi perusahaan.

a. Tujuan Profitabilitas:

Rasio profitabilitas juga memiliki tujuan, tidak hanya bagi pemilik usaha atau manajemen saja, tetapi juga bagi pihak di luar perusahaan, terutama pihak-pihak yang memiliki hubungan atau kepentingan dengan perusahaan.

Menurut Kasmir (2012:197), yang menyatakan bahwa tujuan penggunaan rasio profitabilitas bagi perusahaan, maupun bagi pihak luar perusahaan, yaitu:

1. Untuk mengukur atau menghitung laba yang diperolehperusahaan dalam satu periode tertentu.

2. Untuk menilai posisi laba perusahaan tahun sebelumnya dengan tahun sekarang.

3. Untuk menilai perkembangan laba dari waktu ke waktu.

4. Untuk menilai besarnya laba bersih sesudah pajak dengan modal sendiri. 
5. Untuk mengukur produtkivitas seluruh dana perusahaan yang digunakan baik modal pinjaman maupun modal sendiri.

b. Manfaat Profitabilitas:

1. Mengetahui besarnya tingkat laba yang diperoleh perusahaan dalam satu periode.

2. Mengetahui posisi laba perusahaan tahun sebelumnya dengan tahun sekarang.

3. Mengetahui perkembangan laba dari waktu ke waktu.

4. Mengetahui besarnya laba bersih sesudah pajak dengan modal sendiri.

5. Mengetahui produktivitas dari seluruh dana perusahaan yang digunakan baik modal pinjaman maupun modal sendiri.

Penelitian ini menggunakan rasio Return on Assets (ROA) untuk menghitung rasio profitabilitas.Menurut Irawati (2006:59), yang menyatakan bahwa ROA adalah kemampuan suatu perusahaan (aktiva perusahaan) dengan seluruh modal yang bekerja di dalamnya untuk menghasilkan laba operasi perusahaan (EBIT) atau perbandingan laba usaha dengan modal sendiri dan modal asing yang digunakan untuk menghasilkan laba dan dinyatakan dalam persentase. ROA sering kali disebut sebagai Rentabilitas Ekonomi (RE) atau Earning Power.

Rasio ROA memberikan informasi seberapa efisien bank dalam melakukan kegiatan usahanya, karena rasio ROA mengindikasikan seberapa besar keuntungan yang dapat diperoleh rata-rata terhadap setiap rupiah asetnya (Siamat, 2005:102).

Menurut Bank Indonesia dalam lampiran Surat Edaran (SE) nomor 3/30/DPNP Return On Assets (ROA) merupakan perbandingan antara laba sebelum pajak dengan rata-rata total aset dalam satu periode. Semakin besar Return On Assets (ROA) menunjukkan kinerja perusahaan semakin baik, karena return semakin besar. Sehingga dalam penelitian ini menggunakan Return On Assets (ROA) sebagai indikator pengukur profitabilitas bank. Rumus ROA dapat dijabarkan sebagai berikut:

$$
\text { ROA }=\frac{\text { Laba Sebelum Pajak }}{\text { Total Aset }} \quad 100 \%
$$

\section{METODE PENELITIAN}

Pendekatan penelitian adalah rancangan atau pendekatan yang banyak dipengaruhi olehjenis dan banyaknya variabel. Pendekatan penelitian ini menggunakan pendekatan kuantitatif Pengambilan data pada penelitian ini dilaksanakan pada pusat informasi pasar modal Makassar perwakilan Bursa Efek Indonesia hingga penyelesaiannya dilakukan selama dua bulan. Populasi adalah kumpulan dari seluruh elemen sejenis tetapi dapat dibedakan satu sama lain. Perbedaan - perbedaan itu disebabkan adanya nilai karakteristik yang berlainan.Populasi adalah kumpulan seluruh nilai data observasi dan kemungkinan hasil eksperimen (Sugiyono, 2013:117). Populasi dalam penelitian ini adalah laporan keuangan Bank Persero BUMN di Indonesia (Tahun 2011-2014) yang listing di bursa efek Indonesia yang datanya dihitung secara proporsional dalam bentuk persentase untuk setiap triwulannya, sehingga jumlah data yang akan dianalisis

Author : Rifqi Zul Fahmi dkk. (2016) 27 - 43

Jurnal Ilmiah BONGAYA (Manajemen \& Akuntansi) No. XIX April 2016

ISSN : $1907-5480$ 
sebanyak 64 unit data yang sekaligus digunakan sebagai sampel. (Laporan keuangan Bank pada Tahun 2011 - 20014, untuk PT. Bank Negara Indonesia Tbk., PT. Bank Rakyat Indonesia Tbk, dan PT. Bank Tabungan Negara Tbk, serta PT. Bank Mandiri Tbk).

Analisis statistik inferensial dilakukan dengan menggunakan analisis regresi linear berganda yang analisis datanya dilakukan dengan bantuan program SPSS Ver.22. Penggunaan analisis ini bertujuan untuk menganalisi besaran pengaruh kecukupan modal $\left(\mathrm{X}_{1}\right)$ dan penyaluran kredit $\left(\mathrm{X}_{2}\right)$ terhadap profitabilitas $(\mathrm{Y})$ yang dirumuskan sebagai berikut :

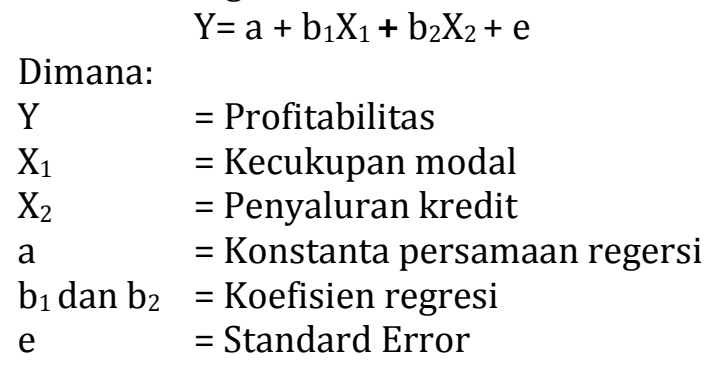

\section{HASIL PENELITIAN}

\section{Statistik Deskriptif Variabel Penelitian}

Statistik deskriptif digunakan untuk memberikan gambaran dan informasi mengenai data variabel dalam penelitian ini.Tabel statistik deskriptif ini meliputi nilai rata-rata (mean), jumlah data $(\mathrm{N})$ dan standar deviasi dari dua variabel independen yaitu Capital Adequacy Ratio (CAR) dan Penyaluran Kredit sebagai variabel yang mempengaruhi Profitabilitas pada Bank Persero BUMN. Hasil analisis deskriptif statistikakan ditunjukkan dalam Tabel di bawah ini:

Tabel 3. Deskripsi Variabel Penelitian Bank Persero BUMN

\begin{tabular}{|l|c|c|c|c|c|}
\hline & $\mathrm{N}$ & Minimum & Maximum & Mean & Std. Deviation \\
\hline Kecukupan Modal (CAR) & 64 & 1.16 & 1.27 & 1.2167 & .02955 \\
\hline Penyaluran Kredit & 64 & 7.70 & 8.69 & 8.3100 & .28892 \\
\hline Profitabilitas (ROA) & 64 & 2.57 & 2.84 & 2.7245 & .07772 \\
\hline Valid N (listwise) & 64 & & & & \\
\hline
\end{tabular}

Sumber: Data diolah SPSS 22 (2015)

Berdasarkan Tabel 3. dapat dilihat bahwa dengan $\mathrm{N}=64$ waktu pengaamatan, variabel dependen profitabilitas mempunyai nilai minimum $1,02 \%$ dan nilai maksimum 5,15\%. Sementara nilai standar deviasi (standard deviation) sebesar $1,16917 \%$ dan nilai rata - rata (mean) sebesar 3,2964\%. Hal ini menunjukkan bahwa selama periode penelitian, secara statistik dapat dijelaskan bahwa profitabilitas perbankan terhadap asetnya termasuk dalam kategori yang cukup yang baik.Adapaun nilai rata - rata (mean) yang lebih besar dibandingkan nilai standar deviasi (standard deviation) menunjukkan bahwa data terdistribusi dengan baik.

CAR mempunyai nilai minimum $14,37 \%$ dan nilai maksimum 18,65\%. Sementara nilai standar deviasi (standard deviation) sebesar $1.12514 \%$ dan

Author : Rifqi Zul Fahmi dkk. (2016) 27 - 43

Jurnal Ilmiah BONGAYA (Manajemen \& Akuntansi) No. XIX April 2016

ISSN : $1907-5480$ 
nilai rata - rata (mean) sebesar $16.5067 \%$.Nilai rata - rata (mean) yang lebih besar dibandingkan nilai standar deviasi (standard deviation) menunjukkan bahwa data terdistribusi dengan baik.Hal ini menunjukkan bahwa secara statistik, selama periode penelitian rasio CAR Bank Persero BUMN belum memenuhi standar yang ditetapkan Bank Indonesia yaitu minimal 8\%.Sementara standar deviasi yang masih lebih kecil jika dibandingkan nilai mean-nya menunjukkan bahwa simpangan data pada CAR relatif baik.

Penyaluran Kredit mempunyai nilai minimum 17,73\% dan nilai maksimum 20,01\%. Sementara nilai standar deviasi (standard deviation) sebesar $0,66585 \%$ dan nilai rata - rata (mean) sebesar $19.1347 \%$. Hal ini menunjukkan bahwa secara statistik, selama periode penelitian variabel independen Penyaluran Kredit memenuhi standar dengan baik.Nilai rata - rata (mean) yang lebih besar dibandingkan nilai standar deviasi (standard deviation) menunjukkan bahwa data terdistribusi dengan baik.

\section{Uji Asumsi Klasik}

Suatu model penelitian dikatakan cukup baik dan dapat digunakan untuk memprediksi jika lolos serangkaian uji asumsi klasik yang melandasinya.Data yang digunakan adalah data sekunder, oleh karena itu untuk menentukan ketepatan model perlu dilakukan pengujian atas beberapa asumsi klasik yang digunakan terdiri dari: uji normalitas, uji multikolinearitas, dan uji heteroskedastisitas.

a. Uji Normalitas

Uji normalitas dapat dilakukan melalui analisis grafik atau dengan analisis statistik untuk mengetahui tingkat signifikansi data apakah data tersebut terdistribusi normal atau tidak.Untuk analisis grafik, dapat dengan melihat normal probability plotdan z-skor yang membandingkan distribusi kumulatif dari distribusi normal.Jika data yang tergambarkan mengikuti garis diagonaldan menyebar disekitar garis diagonal ataunilai data valid dibawah angka 3, berarti data terdistribusi normal (Ghozali, 2013).

Gambar 1. Normal P-P PLOT

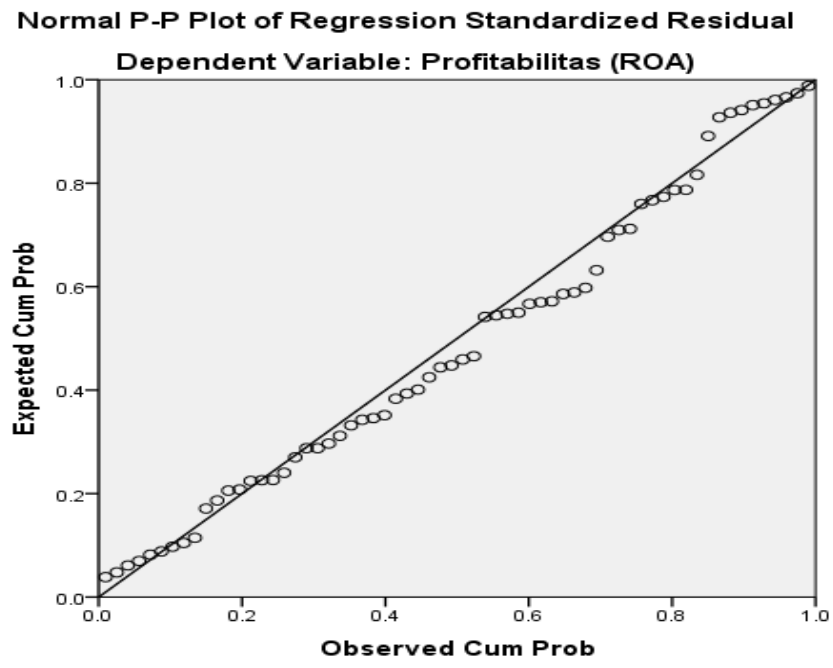

Sumber: Data diolah SPSS 22 (2015)

Author : Rifqi Zul Fahmi dkk. (2016) 27 - 43

Jurnal Ilmiah BONGAYA (Manajemen \& Akuntansi) No. XIX April 2016

ISSN : $1907-5480$ 
Gambar Normal Probability Plot di atas menunjukkan bahwa model regresi memenuhi asumsi normalitas karena data menyebar di sekitar garis diagonal dan penyebaran data searah mengikuti garis diagonal.

Tabel 4. Uji Z-skor Kecukupan Modal (CAR)

\begin{tabular}{|c|c|c|c|c|c|}
\hline \multicolumn{2}{|c|}{} & Frequency & Percent & Valid Percent & Cumulative Percent \\
\hline \multirow{3}{*}{ Valid } & -1.91943 & 1 & 1.6 & 1.6 & 1.6 \\
\cline { 2 - 6 } & 1.80310 & 5 & 7.8 & 7.8 & 100.0 \\
\cline { 2 - 6 } & Total & 64 & 100.0 & 100.0 & \\
\hline
\end{tabular}

Sumber: Data diolah SPSS 22 (2015)

Tabel tersebut menunjukkan nilai z-score terendah -1,91943 dan tertinggi sebesar $1.80310<3,0$ sehingga dapat dijelaskan bahwa data pada variabel kecukupan modal adalah linear sehingga dapat dinyatakan bahwa kecukupan modal (CAR) terbebas dari outlier

Tabel 5. Uji Z-skor Penyaluran Kredit

\begin{tabular}{|c|c|c|c|c|c|}
\hline \multicolumn{2}{|c|}{} & Frequency & Percent & Valid Percent & $\begin{array}{c}\text { Cumulative } \\
\text { Percent }\end{array}$ \\
\hline \multirow{3}{*}{ Valid } & -2.11133 & 1 & 1.6 & 1.6 & 1.6 \\
\cline { 2 - 6 } & 1.31526 & 1 & 1.6 & 1.6 & 100.0 \\
\cline { 2 - 6 } & Total & 64 & 100.0 & 100.0 & \\
\hline
\end{tabular}

Sumber: Data diolah SPSS 22 (2015)

Tabel tersebut menunjukkan nilai z-score terendah -2.11133 dan tertinggi sebesar $1.31526<3,0$ sehingga dapat dijelaskan bahwa data pada variabel penyaluran kredit adalah linear sehingga dapat dinyatakan bahwa penyaluran kredit terbebas dari outlier

Tabel 6. Uji Z-skor Profitabilitas (ROA)

\begin{tabular}{|l|l|r|r|r|r|}
\hline \multicolumn{2}{|c|}{} & \multicolumn{1}{|c|}{ Frequency } & \multicolumn{1}{c|}{ Percent } & Valid Percent & Cumulative Percent \\
\hline \multirow{4}{*}{ Valid } & -1.98820 & 3 & 4.7 & 4.7 & 4.7 \\
\cline { 2 - 6 } & 1.48562 & 2 & 3.1 & 3.1 & 100.0 \\
\cline { 2 - 6 } & Total & 64 & 100.0 & 100.0 & \\
\hline
\end{tabular}

Sumber: Data diolah SPSS 22 (2015)

Tabel tersebut menunjukkan nilai z-score terendah -2.11133 dan tertinggi sebesar $1.31526<3,0$ sehingga dapat dijelaskan bahwa data pada variabel profitabilitas adalah linear sehingga dapat dinyatakan bahwa profitabilitas terbebas dari outlier.

b. Uji multikolinearitas

Uji multikolinearitas bertujuan untuk menguji apakah model regresi ditemukan adanya korelasi antar variabel independen.Model regresi yang baik seharusnya tidak terjadi korelasi antara variabel independen (Ghozali,

Author : Rifqi Zul Fahmi dkk. (2016) 27 - 43

Jurnal Ilmiah BONGAYA (Manajemen \& Akuntansi) No. XIX April 2016

ISSN : $1907-5480$ 
2013). Adanya Multikolinearitas dapat dilihat dari tolerance value atau nilai variance inflation factor (VIF). Suatu model dikatakan bebas dari multikolinearitas jika nilai tolerance $=0,1$ dan memiliki nilai VIF $=10$.

Tabel 7. Uji Multikolinearitas

\begin{tabular}{|c|c|c|c|}
\hline \multicolumn{4}{|c|}{ Coefficients ${ }^{a}$} \\
\hline & & \multicolumn{2}{|c|}{ Collinearity Statistics } \\
\hline \multicolumn{2}{|c|}{ Model } & Tolerance & VIF \\
\hline \multirow[t]{2}{*}{1} & Kecukupan Modal (CAR) & .970 & 1.031 \\
\hline & Penyaluran Kredit & .970 & 1.031 \\
\hline
\end{tabular}

Sumber: Data diolah SPSS 22 (2015)

Berdasarkan tabel di atas, dapat kita lihat bahwa nilai tolerance dan VIF dari variable CAR adalah sebesar 0,970 dan 1,031.Dan variabel Penyaluran Kredit adalah sebesar 0,970 dan 1,031. Oleh karena itu dapat disimpulkan bahwa dalam model ini tidak terjadi multikolinearitas antara variabel bebas karena nilai tolerance lebih besar dari 0,1dan nilai VIF memiliki nilai kecil dari 10 .

\section{Analisis Regresi Liniear ganda}

Dalam penelitian ini, data yang telah dikumpulkan dianalisis dengan menggunakan analisis regresi liniear ganda. Hasil perhitungan regresi liniear berganda dapat di lihat pada tabel dibawah ini:

Tabel 8. Analisis Regresi Liniear ganda

\begin{tabular}{|c|c|c|c|c|c|c|}
\hline \multicolumn{7}{|c|}{ Coefficients $^{a}$} \\
\hline & \multirow[t]{2}{*}{ Model } & \multicolumn{2}{|c|}{$\begin{array}{l}\text { Unstandardized } \\
\text { Coefficients }\end{array}$} & \multirow{2}{*}{$\begin{array}{c}\begin{array}{c}\text { Standardiz } \\
\text { ed } \\
\text { Coefficients }\end{array} \\
\text { Beta } \\
\end{array}$} & \multirow[t]{2}{*}{$\mathrm{t}$} & \multirow[t]{2}{*}{ Sig. } \\
\hline & & $\mathrm{B}$ & Std. Error & & & \\
\hline \multirow[t]{3}{*}{1} & (Constant) & .349 & .239 & & 1.461 & .149 \\
\hline & $\begin{array}{l}\text { Kecukupan Modal } \\
\text { (CAR) }\end{array}$ & .466 & .176 & .177 & 2.649 & .010 \\
\hline & Penyaluran Kredit & .218 & .018 & .809 & 12.095 & .000 \\
\hline
\end{tabular}

Sumber: Data diolah SPSS 22 (2015)

Dari Tabel di atas, dengan memperhatikan angka yang berada pada kolom Unstandardized Coefficient Beta, maka dapat disusun persamaan regresi liniear berganda sebagai berikut:

\section{$Y=0,349+0,466 X_{1}+0,218 X_{2}+0,239$}

Berdasarkan hasil perhitungan diatas, maka persamaan regresi liniear berganda dapat diinterprestasikan sebagai berikut:

a. Nilai konstanta persamaan diatas adalah 0,349, angka tersebut menunjukkan tingkat Profitabilitas yang diperoleh oleh Bank Persero BUMN bila tingkat CAR $\left(\mathrm{X}_{1}\right)$ dan Penyaluran Kredit $\left(\mathrm{X}_{2}\right)$ diabaikan. Artinyajika nilai variabel (bebas) nol maka nilai varibel dependen(terikat) sebesar 0,349 dalam hal ini jika CAR dan

Author : Rifqi Zul Fahmi dkk. (2016) 27 - 43

Jurnal Ilmiah BONGAYA (Manajemen \& Akuntansi) No. XIX April 2016

ISSN : $1907-5480$ 
Penyaluran Kredit bernilai 0,000 (nol) maka profitabilitas akan mengalami peningkatan sebesar $0,349 \%$.

b. Variabel Capital Adequacy Ratio (CAR) memiliki nilai koefisien regresi yang positif yaitu sebesar 0,466 . Nilai koefisien positif menunjukkan bahwaCAR terhadap Profitabilitas berpengaruh positif. Hal ini menggambarkan bahwa jika terjadi kenaikan CAR sebesar 1 persen, maka Profitabilitasakan mengalami peningkatan sebesar 0,466\% dengan asumsi variable independen lain dianggap konstan.

c. Variabel Penyaluran Kredit memiliki nilai koefisien regresi yang positif yaitu sebesar 0,218. Nilai koefisien positif menunjukkan bahwa Penyaluran Kredit terhadap Profitabilitas berpengaruh positif. Hal ini menggambarkan bahwa jika terjadi kenaikan Penyaluran Kredit sebesar 1 persen, maka Profitabilitasakan mengalami peningkatan sebesar $0,218 \%$ dengan asumsi variabel independen lain dianggap konstan.

\section{Uji Model (f-test)}

Uji Fisher dikenal digunakan untuk melihat apakah model yang dianalis telah memenuhi kriteria kesesuaian yang dipersyaratkan. f-test dapat dilakukan dengan mebandingkan f-hitung dengan f-tabel, jika f-hitung > dari f-tabel maka model dinyatakan ditolak atau tidak memenuhi goodnes of fit, sebaliknya jika jika fhitung < dari f-tabel, maka model dinyatakan diterima atau memenuhi goodnes of fit

Tabel 9. f-test

\begin{tabular}{|l|l|r|r|r|r|r|}
\hline \multicolumn{7}{|l|}{ ANOVA $^{\mathbf{a}}$} \\
\hline \multirow{3}{*}{$\begin{array}{l}\text { Model } \\
1\end{array}$} & Sum of Squares & df & Mean Square & F & Sig. \\
\cline { 2 - 7 } & Regression & .280 & 2 & .140 & 84.709 & $.000^{\mathrm{b}}$ \\
\cline { 2 - 7 } & Residual & .101 & 61 & .002 & & \\
\cline { 2 - 7 } & Total & .381 & 63 & & \\
\hline
\end{tabular}

Sumber: Data diolah SPSS 22 (2015)

Berdasarkan Tabel tersebut diatas didapat nilai $F_{\text {hitung }}$ sebesar 84,709 dengan signifikansi 0,000 . Oleh karena $F_{\text {hitung }} 84,709>F_{\text {tabel }} 3,15$ maka Ha diterima dan Ho ditolak dan nilai signifikansi lebih kecil dari 0,05. Sehingga model dinyatakan diterima atau memenuhi goodnes of fit

\section{Uji Hipotesis (t-test)}

t-test pada dasarnya menunjukkan seberapa jauh pengaruh satu variabel independen yang terdiri dari Kecukupan Modal (CAR) dan Penyaluran Kredit secara parsial terhadap variabel dependen yaitu Profitabilitas. Hasil pengujian secara parsial dapat dilihat pada Tabel 4.8 berikut ini:

Tabel 10. t-test

Coefficients $^{\mathrm{a}}$

Author : Rifqi Zul Fahmi dkk. (2016) 27 - 43

Jurnal Ilmiah BONGAYA (Manajemen \& Akuntansi) No. XIX April 2016

ISSN : $1907-5480$ 


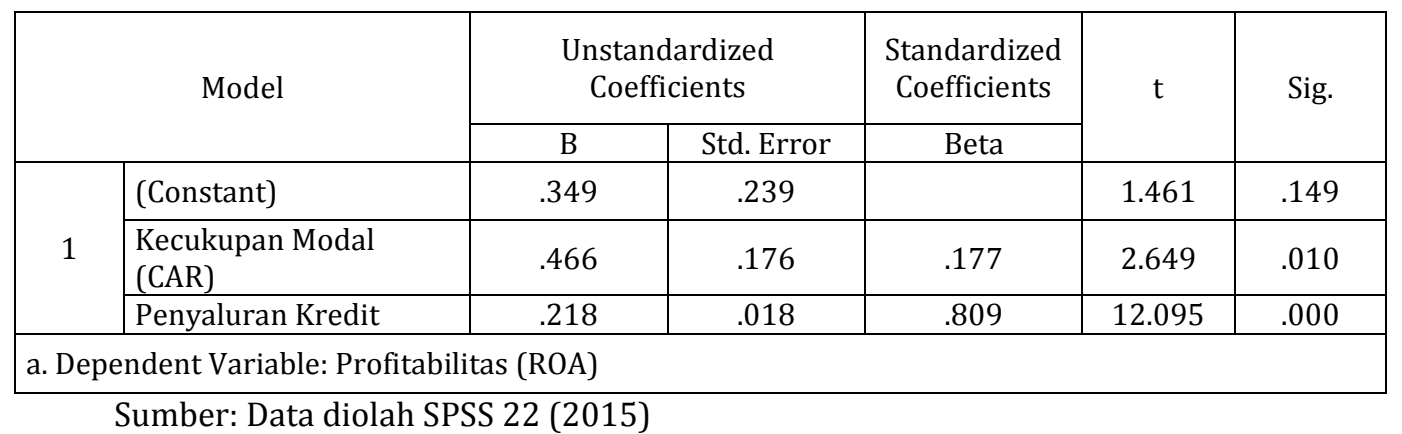

Hasil t-test pada Tabel tersebut menunjukkan bahwa pengaruh dari variable Kecukupan Modal (CAR) dan Penyaluran Kredit terhadap Profitabilitasdapat dilihat dari thitung dan tingkat signifikansi (probabilitas).Variabel Kecukupan Modal (CAR) memiliki thitung sebesar 2,649> tabel 1,670 sehingga Ha diterima dan Ho ditolak dan dalam nilai signifikan CAR 0,10 > 0,05 sehingga Ha ditolak dan Ho diterima. Variabel Penyaluran Kredit memiliki $t_{\text {hitung }} 12,095>t_{\text {tabel }} 1,670$ dan nilai signifikan Penyaluran Kredit 0,00< 0,05 sehingga Ha diterima dan Ho ditolak.Dengan demikian variabel Kecukupan Modal (CAR) memiliki pengaruh positif tetapi tidak signifikan terhadap Profitabilitas, sedangkan variabel Penyaluran Kredit berpengaruh positif dan signifikan terhadap Profitabilitas.

6. Koefisien Determinasi

Koefisien determinasi $\left(\mathrm{R}^{2}\right)$ pada intinya mengukur seberapa jauh kemampuan model dalam menerangkan variasi variabel dependen.Nilai koefisien determinasi berada di antara nol dan satu $\left(0 \leq R^{2} \leq 1\right)$.Nilai $\left(R^{2}\right)$ yang kecil berarti kemampuan variabel-variabel independen dalam menjelaskan variabel dependen amat terbatas.Nilai yang mendekati satu berarti variabel-variabel independen memberikan hampir semua informasi yang dibutuhkan untuk memprediksi variasi variabel dependen (Ghozali, 2013).Hasil uji koefisien determinasi dapat dilihat pada Tabel berikut ini:

Tabel 11. Koefisien Determinasi $\left(R^{2}\right)$

\begin{tabular}{|c|c|c|c|c|}
\hline \multicolumn{5}{|c|}{ Model Summaryb } \\
\hline Model & $\mathrm{R}$ & R Square & Adjusted R Square & $\begin{array}{l}\text { Std. Error of the } \\
\text { Estimate }\end{array}$ \\
\hline 1 & $.857 a$ & .735 & .727 & .04064 \\
\hline \multicolumn{5}{|c|}{ a. Predictors: (Constant), Penyaluran Kredit, Kecukupan Modal (CAR) } \\
\hline b. Depe & riable: $\mathrm{Pr}$ & tabilitas (RO & & \\
\hline
\end{tabular}

Sumber: Data diolah SPSS 22 (2015)

Dari Tabel diatas dapat diketahui koefisien determinasi yang ditunjukkan dari nilai adjusted $R^{2}$ sebesar 0,727, dengan ini dapat diartikan bahwa $72,7 \%$ variabel Profitabilitas dapat dijelaskan oleh variabel Kecukupan Modal (CAR) dan Penyaluran Kredit. Sedangkan sisanya 27,3\% dipengaruhi oleh variabel lain yang tidak dimasukkan dalam model

Author : Rifqi Zul Fahmi dkk. (2016) 27 - 43

Jurnal Ilmiah BONGAYA (Manajemen \& Akuntansi) No. XIX April 2016

ISSN : $1907-5480$ 
penelitian ini. Dengan demikian, hubungan kedua variabel bisa dikatakan kuat karena nilai R square hampir mendekati angka 1.

\section{E. Pembahasan hasil penelitian}

\section{Hasil Pengujian Hipotesis}

Dari model persamaan regresi yang digunakan, ada tiga hipotesis yang diuji yaitu :

a. $\mathrm{H}_{1}=$ Kecukupan modal (CAR) berpengaruh positif signifikan terhadap Profitabilitas pada Bank Persero BUMN periode 20112014. Berdasarkan hasil penelitian menunjukkan bahwa CAR berpengaruh positif tetapi tidak signifikan terhadap Profitabilitas. Hal ini didasari pada hasil uji t yang telah dilakukan yaitu Variabel Kecukupan Modal (CAR) memiliki thitung sebesar 2,649 $>t_{\text {tabel }}$ 1,670 sehingga Ha diterima dan Ho ditolak dan dalam nilai signifikan CAR 0,10 > 0,05 sehingga Ha ditolak dan Ho diterima.Dengan demikian hasil dari uji t menunjukkan bahwa Kecukupan Modal (CAR) terhadap Profitabilitas berpengaruh positif tidak signifikan, sehingga hipotesis pertama tidak dapat diterima.

Dari hasil uji analisis yang telah dilakukan dapat diketahui yaitu Capital Adequacy Ratio berpengaruh positif tidak signifikanterhadap profitabilitas pada bank.Hasil ini menolak penelitian yang dilakukan oleh Ade Firmansyah(2013). Kemudian sejalan dengan penelitian yang dilakukan Wisnu Mawardi (2004) bahwa Kecuupan Modal (CAR) mempunyai pengaruh positif tidak signifikan terhadap jumlah Profitabilitas.

Hasil penelitian ini mengindikasikan bahwa meningkat atau menurunnyaCapital Adequacy Ratio berpengaruh positifterhadap Profitabilitas.Capital adequacy ratio(CAR) sebagai faktor internal bank berpengaruh atas tingkat kesehatan bank yang mewakili kecukupan modal bank. Modal yang cukup akan membantu kegiatan operasional. Selain itu, bank dengan kecukupan modal yang baik, bank akan diuntungkan pada saat-saat keadaan ekonomi yang buruk karena bank berada di posisi yang aman karena mempunyai cadangan modal di Bank Indonesia.

Adapun rata - rata CAR Bank Persero BUMN pada periode 20112014 berada pada kisaran yang cukup tinggi yakni sekisar 14,37$18,65 \%$ dan jauh diatas ketentuan minimal yang disyaratkan oleh Bank Indonesia sebesar 8\%. Tingginya CAR mengindikasikan adanya sumber daya finansial (modal) yang menganggur.Tingginya nilai CAR mungkin disebabkan oleh sebagian besar dana yang telah diperoleh dari aktivitas perbankan dialokasikan pada cadangan minimum bank atau digunakan untuk menutupi potensi kerugian yang diakibatkan oleh kegiatan aktivitas bank.

Semakin tinggi CAR maka semakin besar pula sumber daya finansial yang dapat digunakan untuk mengantisipasi potensi kerugian

Author : Rifqi Zul Fahmi dkk. (2016) 27 - 43

Jurnal Ilmiah BONGAYA (Manajemen \& Akuntansi) No. XIX April 2016

ISSN : $1907-5480$ 
yang diakibatkan oleh penyaluran kredit. Secara singkat dapat dikatakan besarnya nilai CAR akan meningkatkan kepercayaan diri perbankan dalam menyalurkan kredit. Dengan CAR di atas 20\%, perbankan bisa memacu pertumbuhan kredit hingga 20-25 persen setahun.Kiat yang banyak ditempuh oleh bank untuk memperkuat CAR dalam rangka menggenjot ekspansi kredit pada tahun berikutnya adalah dengan penerbitan obligasi subordinasi (subdebt) dan right issue.

b. $\mathrm{H}_{2}=$ Penyaluran kredit berpengaruh positif signifikan terhadap Profitabilitas pada Bank Persero BUMN periode 2011-2014. Berdasarkan hasil penelitian menunjukkan bahwa Penyaluran Kreditberpengaruh positif terhadap Profitabilitas.Hal ini didasari pada hasil uji t yang telah dilakukan yaitu variabel Penyaluran Kredit memiliki $\mathrm{t}_{\text {hitung }} 12,095>\mathrm{t}_{\text {tabel }} 1,670$ dan nilai signifikan Penyaluran Kredit 0,00< 0,05 sehingga Ha diterima dan Ho ditolak. Dengan demikian hasil dari uji t menunjukkan bahwa Penyaluran Kredit terhadap Profitabilitas berpengaruh positif dan signifikan, sehingga hipotesis kedua dapat diterima.

Dari hasil uji analisis yang telah dilakukan dapat diketahui yaitu Penyaluran Kredit berpengaruh positif signifikan dan lebih dominan terhadap profitabilitas pada bank.Hasil ini mendukung penelitian yang dilakukan Firmansyah (2013) dan menolak temuan penelitian yang dilakukan Wisnu Mawardi (2004) bahwa Penyaluran Kredit mempunyai pengaruh positif signifikan terhadap jumlah Profitabilitas

Hasil penelitian ini mengindikasikan bahwa semakin tinggi atau kecilnya Penyaluran Kredit yang disalurkan maka sangat berpengaruh terhadap Profitabilitas. Oleh karena itu Penyaluran Kredit merupakan variabel yang memiliki pengaruh paling besar terhadap Profitabilitas perbankan.Hal ini tidak lepas dari fungsi bank yaitu berfungsi sebagai perantara keuangan untuk kemudian disalurkan kembali kepada masyarakat yang membutuhkan dalam bentuk kredit. Penyaluran Kredit merupakan sumber dana terbesar yang paling diandalkan oleh bank (Dendawijaya, 2009:49). Hal tersebut dikarenakan salah satu tujuan bank adalah mendapatkan profit, sehingga bank tidak akan menganggurkan dananya begitu saja. Bank cenderung untuk menyalurkan dananya semaksimal mungkin guna memperoleh keuntungan yang maksimal pula.

c. $\mathrm{H}_{3}=$ Penyaluran kredit merupakan variabel yang dominan berpengaruh terhadap Profitabilitas pada Bank Persero periode 2011-2014. Berdasarkan hasil penelitian menunjukkan bahwa Penyaluran Kredit berpengaruh lebih dominan terhadap Profitabilitas pada bank. Hal ini didasari pada analisis linear berganda yang telah dilakukan yaitu variabel Penyaluran Kredit memiliki nilai Standardized Coefficients sebesar 0,809 yang jauh lebih besar dibandingkan dengan nilai Standardized

Author : Rifqi Zul Fahmi dkk. (2016) 27 - 43

Jurnal Ilmiah BONGAYA (Manajemen \& Akuntansi) No. XIX April 2016

ISSN : $1907-5480$ 
Coefficientsvariabel CAR yaitu 0,177. Oleh karena itu hipotesis yang ketiga dapat diterima.

\section{F. Kesimpulan}

Kecukupan Modal (Capital Adequacy Ratio) beperngaruh positif tidak signifikan dan Penyaluran Kredit berpengaruh positif signifikan terhadap Profitabilitas pada 4 Bank Persero BUMN periode penelitian 2011-2014.

Perbankan hendaknya mempertahankan kinerjanya dalam mempertahankan jumlah CAR yang cukup tinggi jauh dari batas minimum yang ditentukan oleh Bank Indonesia. CAR yang cukup akan membantu kegiatan operasionalsehingga untuk mempertahankan nilai CAR yang cukup tinggi, mengharuskan Bank untuk lebih optimal dalam memanfaatkan kegunaan sumber daya finansial (modal) yang dimiliki melalui penyaluran kredit (sektor produktif).

Penyalurkan kredit kepada masyarakat luas yang membutuhkan kredit dapat dipertahankan, baiknya lagi ditingkatkan agar perusahaan perbankan dapat lebih berkembang lebih besar. Untuk mempertahankan nilai Penyaluran Kredit dapat dilakukan antara lain melalui program reward yang menarik, direct selling, pameran, komisi karyawan dan pihak lain, menggabungkan kartu kredit dengan produk perbankan lainnya, promosi online.

\section{Daftar Pustaka}

Bank Indonesia. (2010). Laporan Bank Indonesia. Jakarta

Dendawijaya, Lukman. (2009). Manajemen Perbankan, Edisi Kedua, Ghalia Indonesia, Jakarta

Firmansyah, Ade. (2013). Analisis Pengaruh Dana Pihak Ketiga, Kecukupan Modal, Penyaluran Kredit, dan Efisiensi Operasi terhadap Profitabilitas Bank (Studi kasus Pada Bank Persero Periode Tahun 2009-2012),

Ghozali, Imam, (2013). SPSS 21 Aplikasi Analisis Multivariate Dengan Program SPSS, Universitas Diponogoro, Semarang.

Irawati, Susan, (2006). Manajemen Keuangan. Alfabeta, Bandung

Isnanta. (2008). Pengaruh Corporate Governance dan Struktur Kepemilikan terhadap Manajemen Laba dan Kinerja Keuangan, journal Universitas Islam Indonesia. Yogyakarta

Kasmir, (2012). Manajemen Perbankan, Edisi Revisi 2012, PT. RajaGrafindo Persada, Jakarta

Kasmir. (2014). Bank dan Lembaga Keuangan Lainnya. Edisi Revisi. PT. RajaGrafindo Persada, Jakarta.

Lestari, I , Maharani \& Sugiharto, Toto (2007). Kinerja Bank Devisa dan Bank Non Devisa dan Faktor-Faktor Yang Memengaruhinya, Jurnal PESAT (Psikologi, Ekonomi, Sastra, Arsitek \& Sipil)

Mawardi, Wisnu. (2005). Pengaruh Rasio Kesehatan Bank Terhadap Kinerja Keuangan Bank Umum Syariah dan Bank Konvensional di Indonesia. Jurnal Analisis.

Republik Indonesia (1998) Undang - undang Perbankan Nomor 10. Jakarta

Siamat, Dahlan. (2005). Rasio Keuangan Dalam Perbankan,Salemba Empat,Jakarta

Sugiyono. (2013). Metode Penelitian Pendidikan, Alfabeta, Bandung.

Triandaru, Sigit \& Santoso, A. Totok Budi, (2006). Bank dan Lembaga Keuangan Lain, Edisi Kedua, Salemba Empat, Jakarta.

Author : Rifqi Zul Fahmi dkk. (2016) 27 - 43

Jurnal Ilmiah BONGAYA (Manajemen \& Akuntansi) No. XIX April 2016

ISSN : $1907-5480$ 